graphed. Results of the control experiment are shown in Fig. 1, while Fig. 2 shows the precipitin lines of antigenantibody in agar medium which was infused with dextran solution.

The time sequence of the appearance of precipitin lines was as follows: first, the less diffusible antigen(s) precipitated out, while lastly tho most diffusible antigen(s) formed a precipitate. Possibly the aggregated part of insulin, if any, was precipitated first, while the precipitin reaction betweon loss aggrogated insulin molecules and the antibody took longer.

It has bet $n$ suggested ${ }^{9-13}$ that polysaccharides may exclude some proteins from solution rather than interacting with them. Dextran seems to decrease the solubility of immuno-complexes in agar gel medium and helps to exclude them.

Department of Biochemistry,

M. CESKA

Pharmacia $\mathrm{AB}$,

Uppsala, Sweden.

Recelved November 24; revisea December $22,1967$.

1 Ouchterlony, 0., Acta Pathol. Microbial. Scand.. 25, 186 (1948).

'Moloney, P. J., and Aprile, M. A., Canad. J. Biochem. Physiol., 37, 703 (1959).

${ }^{3}$ Tones, V. E., and Cunliffe, A. C., Nature, 192, 136 (1981). Stelgerwald, H, Spielman, W., Fries, H., and Grebe, S. T., Klin. Woch.,
38, 973 (1900).

Birkinshaw, V. J., Randall, S. S., and Risdall, P. C., Nature, 193, 1080 (1962).

- Grabar, P., and Williams, C. A., Biochim. Biophys. Acta, 10, 193 (1953).

${ }^{7}$ Grabar, P., and Williams, Q, A., Biochim. Biophys. Acta, 17, 67 (1955).

${ }^{8}$ Wide, L., and Porath, J., Biochim. Biophys. Acta, 130, 257 (1966).

"Ogston, A. G., and Plielys, C. F., Biochem. I., 78, 827 (1961).

10 Laurent, T. C., Biochem. J., 89, 253 (1963).

1 Laurent, T. C., Acta Chem. Scand., 17, 2604 (1963).

${ }^{12}$ Hellsing, K., and Laurent, T. C., Acta Chem. Scand., 18, 1303 (1964).

${ }^{13}$ Iverius, P. H., and Laurent, T. C., Biochim. Bowphys. Actu, 133, 371 (1967).

\section{Occurrence of Haemocoelic Erythrocytes containing Haemoglobin in a Wood Boring Molluse}

DURING recent studies of tho rock and wood boring molluses of the super-family Adesmacea (Mollusea : Bivalvia) the occurrence of haemoecolic erythrocytes in the blood of Xylophaga dorsalis Turton was noticed whilo

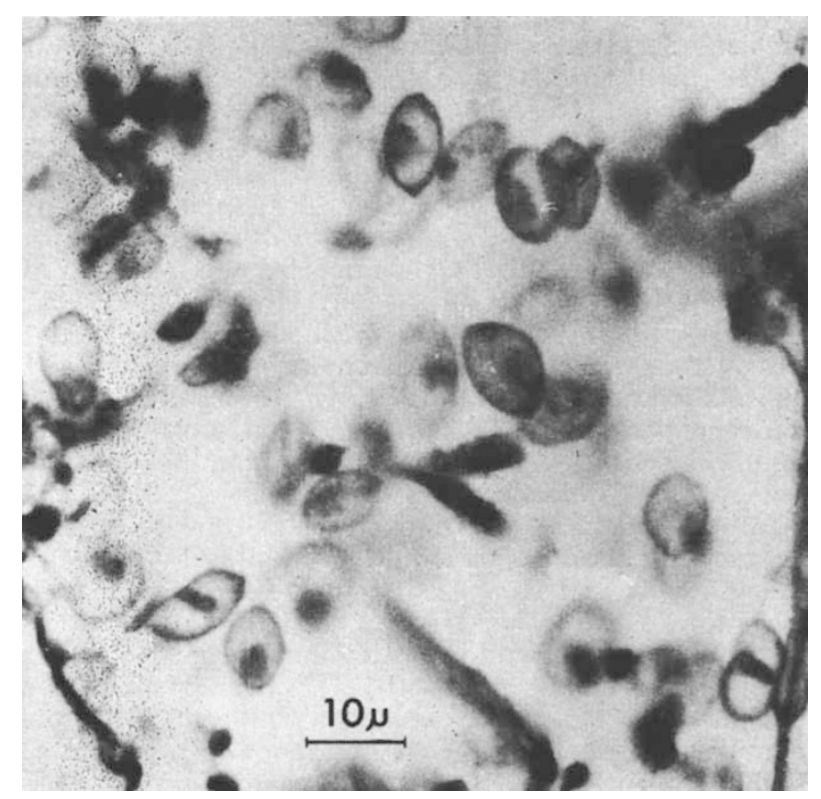

Fig. 1. A group of haemonelic erythrucytes in a linosl sinus of Yylophaga dorsalis. examining serial sections. The erythrocytes are slightly flattened disks of diameter $10-12 \mu$, each cuntaining a, prominent nucleus (Fig. 1).

Tho blocd of this species possesses a light pinkish colour, and our observations suggest that this lint is a consequence of the presence of haemoglobin in the crythrocytes. Dried smears of the blood gave a positive result to the bcnzidine reaction ${ }^{1}$ which stained only the erythrocytes dark blue, while a dilute solution of the pigment in distilled wator showed a major absorption peak at $415 \mathrm{~m} u$, and indications of $\alpha$ and $\beta$ peaks at $578 \mathrm{~m} \mu$ and $540 \mathrm{~m} \mu$. Treatment with carbon monoxide caused a shift in the major absorption peak to $420 \mathrm{~m} \mu$ and of the $\alpha$ peak to $568 \mathrm{~m} \mu$. These changes are consistent with the transformation of oxy-haemoglobin to carboxy-haemoglobin and with previous knowledge of absorption spectra of molluscan hacmoglobins ${ }^{2}$, and are therefore taken as confirmation that the pigmont in Xylophaga is a haemoglobin.

The possession of haemoglobin by a member of the Adesmacea has not been reported before, although myo. globin occurs in the adductor muscle of spccies of Bankia and Tered ${ }^{3}$. The isolated instances of the occurrences of haemoglobin in solution in the haemolymph, in the ctenidium, and in hacmocoelic erythrocytes elsewhere in the Bivalvia, havo been reviewed recently. Interpreta. tion of the function of the haemoglobin of Xylophaga, a species which is usually found attacking submerged waterlogged timber ${ }^{5}$, must await more detailed biochemical and physiological investigations of its properties.

This work was carried out during tho tenure of a Royal Society and Nuffield Foundation Commonwealth bursary held by one of us (N. B. N.).

Marine Station,

A. D. ANswiLL

Millport, Scotland.

Oceanographic Laboratory,

N. BALAKRISHNAN NAIR

University of Kerala,

Ernakulam, India.

Received lecember $18,1987$.

${ }^{1}$ Pearse, A. G. F., Histochemistry, Themetiral and Apptied, second ed, (f. and A. Churchill, Ltd., Lundon, i960).

"Prosser, C. L., and Brown, jun., F. A., Comparative A nimal Physiology (Saunders, Philadelphia, Pennsylvania, 1961).

${ }^{3}$ Manwell, C., Comp. Biochem, Physiol., 8, 209 (1063).

'Read, K. R. H., in Physiology of Mollusca (edit. hy Wilbur, K. M., and Yonge, $\therefore$ M.), 2 (A sademic Press, New York, 1966). 'Tebblc, N., British Bivalve Seashells (British Museum [Natural History],
Iondon, 1966).

\section{Specific Method for Estimating Cell Numbers in Tendons}

STUDIEs of growth, agoing and functional adaptation of dense regular connective tissue of tendons and ligaments are limited because of the lack of a simple accurate method for the estimation of the cell populations involved ${ }^{1}$. Standard histometric techniques for cell counting are ospocially difficult to apply to tough intractable, fibrous tissues, and there is an obvious need for a simpler quantitative melhod which is accurate, reproducible and rapid.

If the amount of DNA in the somatic diploid cell nueleus is known, and if total tissue DNA can be extracted, cell numbers can be readily calculated, for it has been shown that the diploid amount of DNA in the coll nuelei is constint for a particular species 2 . This fact is tho basis of a number of growth and cell population studies involving wholo animals and tissues. ${ }^{3}$. These mothods havo, howevor, nevor been applied to denso, fibrous, relatively acellular tissues such as tendons and ligaments. 